\title{
CORPORATE BOND MARKETS IN EASTERN EUROPE: TRENDS AND PROSPECTS
}

\author{
Dariia Vasylieva ${ }^{1}$
}

\begin{abstract}
The purpose of the paper is to analyze the process of the corporate bond market formation in Eastern Europe and to determine the prospects for development in Ukraine. Methodology. It is justified that the main variables that affect corporate bond issues are loans granted to financial corporations (excluding banks) and non-financial corporations, share issues and equity. The empirical basis of the study is the reports of the National Securities and Stock Market Commission (on the amount of shares and bonds), the National Bank of Ukraine (on the amount of loans to corporations) and the State Statistics Service of Ukraine (on the amount of corporate equity). The study covers 20 years: from 2000 to 2019. Based on these data, a vector autoregressive model (VAR) was constructed. The forecast error variance decomposition (VDC) technique was used to identify the most influential variables in the corporate bond issuance process. Based on the VAR model, the forecast levels of model variables for 2021-2024 were obtained, which should have been achieved under the condition of planned development of the corporate bond market in Ukraine. It has been suggested that the economic shock of the COVID-19 has led to a decrease in the expected level of variables in 2020. Therefore, seven scenarios for the development of the corporate bond market are considered: $A$ - reduction of equity amount; $B$ - decrease in the amount of shares issued; $C$ - decrease in the amount of loans to corporations; $A+B ; A+C ; B+C ; A+B+C$. The results of the VDC technique have allowed to establish that the issue of corporate bonds in Ukraine largely depends on the amount of bank loans granted to corporations. Based on the VAR model and scenario forecasting, it was determined that the most favorable for the development of the corporate bond market of Ukraine is the scenario, in which corporations' equity will be reduced by $10 \%$ due to increased uncovered loss but such a reduction will not lead to liquidation, and hence the cessation of circulation of their shares. Practical implications. Forecasting the amount of corporate bonds, shares and loans to corporations based on the proposed model allows companies to develop effective strategic plans, and investors to decide on the allocation of their own financial resources. Value/originality. The proposed model of corporate bond market development in Ukraine includes internal and external sources of financing of enterprises, and allows to quantify the relationship between financial instruments (corporate bonds, loans and shares).
\end{abstract}

Key words: bank loans, corporate bond market, corporate bonds, equity, shares, VAR analysis.

JEL Classification: C32, G17, G30

\section{Introduction}

In a dynamic environment, businesses are constantly facing with the need to raise additional capital to ensure current and future goals. The sources of capital acquisition by enterprises have long been one of the most important research topics and problems in economic practice. The financial market and, more broadly, the financial system play an extremely important role in raising capital for all enterprises. Formation and maintenance of competitive positions in the modern conditions is practically impossible without financing the needs of enterprises from external sources. One such source is the issuance of corporate bonds. Therefore, ensuring that you have sufficient financial resources is important at every stage of the company's life cycle.

Corporate bonds have become increasingly popular in recent decades due to their diversification and higher reliability for investors compared to other debt instruments. Nevertheless, the possibility of active use of this financial instrument in the activities of enterprises, as well as its availability to investors largely depends on the current state of the national corporate bond market.

The development of the corporate debt securities market can create an alternative to bank lending. However, at present in most Eastern European countries, the corporate debt market, as well as the securities

\footnotetext{
Corresponding author:

${ }^{1}$ Kyiv National Economic University named after Vadym Hetman, Ukraine.

E-mail: d.vasilieva@yahoo.co.uk

ORCID: https://orcid.org/0000-0001-8190-3321

ResearcherID: https://publons.com/researcher/4225041/dariia-vasylieva/
} 
market in general, is in its infancy. The indicators of the development of the corporate debt securities market are far from the level not only of bank lending, but also of the government securities market. In Ukraine, the corporate bond market is under development, but many decisions are being made at the regulatory level to ensure its dynamic development. This study focuses on the main trends in the development of the corporate bond market in Ukraine, as well as the establishment of dependence on equity, stocks, and bank loans as sources of enterprise financing.

The development of the corporate bond market in Eastern Europe is the subject of research by many scholars, including: Haiss P., Marin S. (Haiss, 2003), Gozzi J., Levine R., Peria M. (Gozzi, 2015), Ayala Pena D., Nedeljkovic M., Saborowski C. (Ayala Pena, 2017), Kubiczek J. (Kubiczek, 2020). In addition, trends and prospects for the development of corporate bond markets in certain countries are disclosed in the reports of the International Capital Market Association (ICMA, 2020), The International Organization of Securities Commissions (IOSCO, 2020), The Organization for Economic Co-operation and Development (OECD, 2020), and the European Commission Expert Group (European Commission Expert Group, 2017).

\section{The analysis of corporate bond markets in Eastern Europe}

Given that this study focuses on attracting financial resources to the activities of enterprises based on the issuance of corporate bonds, it is advisable to analyze the balance sheet of corporations in Eastern Europe, namely the volume of corporate bonds and credit resources in the balance sheet liabilities and relevant financial operations (transactions). Therefore, we propose to conduct a comparative analysis of raising funds based on these two sources in the corporate sector during 2014-2020 in Eastern European countries such as Bulgaria, Poland, Romania, Slovakia, Slovenia, Hungary, Croatia, and the Czech Republic. The volume of lending to the corporate sector was chosen as a comparative indicator for the analysis, as corporate bonds are the financial instrument that displaces bank loans due to their progressiveness and efficiency. The dynamics of the debt burden on corporations from bonds and loans in these countries is shown in Figure 1.

In Bulgaria, Romania, and Croatia, over the past seven years, there has been an inversely proportional trend between loan payments and bond payments. Therefore, during periods of accumulation of financial resources from the sale of corporate bonds, there are predominant payments on bank loans, and vice versa.

For Poland, Slovakia and the Czech Republic, 2014-2019 is a period of active attraction of financial resources both through the sale of bonds and through bank lending, as the difference between borrowed funds and debt repayment costs is positive throughout the period. Exceptions are: Poland corporations in 2018 carried out more financial transactions for the payment of interest on bonds than for the sale of bonds; in Slovakia (2014) with predominant financial transactions on debt repayment on loans and 2020 on corporate bonds; in the Czech Republic (2015) with predominant financial transactions to repay debt on loans, and 2020 - for corporate bonds.

In Hungary and Slovenia, the periods of accumulation and repayment of the investigated debt instruments coincide. It is worth noting that in Hungary, transactions to raise financial resources exceed transactions in the payment of interest from 2017, and in Slovenia - from 2020.

The circulation of corporate bonds in 2020 was complicated by the shock of the coronavirus pandemic. As uncertainty increased during the first weeks of March 2020 due to downgrades, potential defaults and withdrawals from corporate bond funds, dealers were reluctant to stockpile on their balance sheets. As a result, dealers tried to shift certain activities from the main to the agency trade, and also demanded a much higher price for intermediary activities. After the intervention of securities regulators, liquidity conditions improved, although not to the levels observed before the shocks caused by COVID-19 (Kargar, 2020).

\section{The main trends of the corporate bond market in Ukraine}

The main period of the corporate bond market development in Ukraine is the period of activation (from 2002 to 2007). Thus, the dynamic growth of the corporate bond market during 2002-2007 coincides with the general trends in the domestic market: growth of the market confidence level; increase in number of financial intermediaries; the market becomes important as an investment environment for the accumulation and distribution of financial resources; the necessary conditions for its functioning are created (Kuzheliev, 2019).

During 2012-2019, there was a decline in the dynamics of indicators: if in 2012 the total issue of corporate bonds amounted to 51.39 billion UAH (3.66\% of GDP), in 2019 - 11.21 billion UAH ( $0.28 \%$ of GDP). Thus, the annual amount of issues decreased $7.5 \%$ (Figure 2).

The National Commission on Securities and Stock Market report for October 2020 makes it possible to state that the volume of the corporate bond market in Ukraine is currently growing, as 74 corporate bonds worth 29.35 billion UAH were issued in ten months, which is higher than in 2014 . This, in turn, is $1.63 \%$ of GDP, which almost reaches the level of 2014. It should be noted that these issues were made by enterprises 


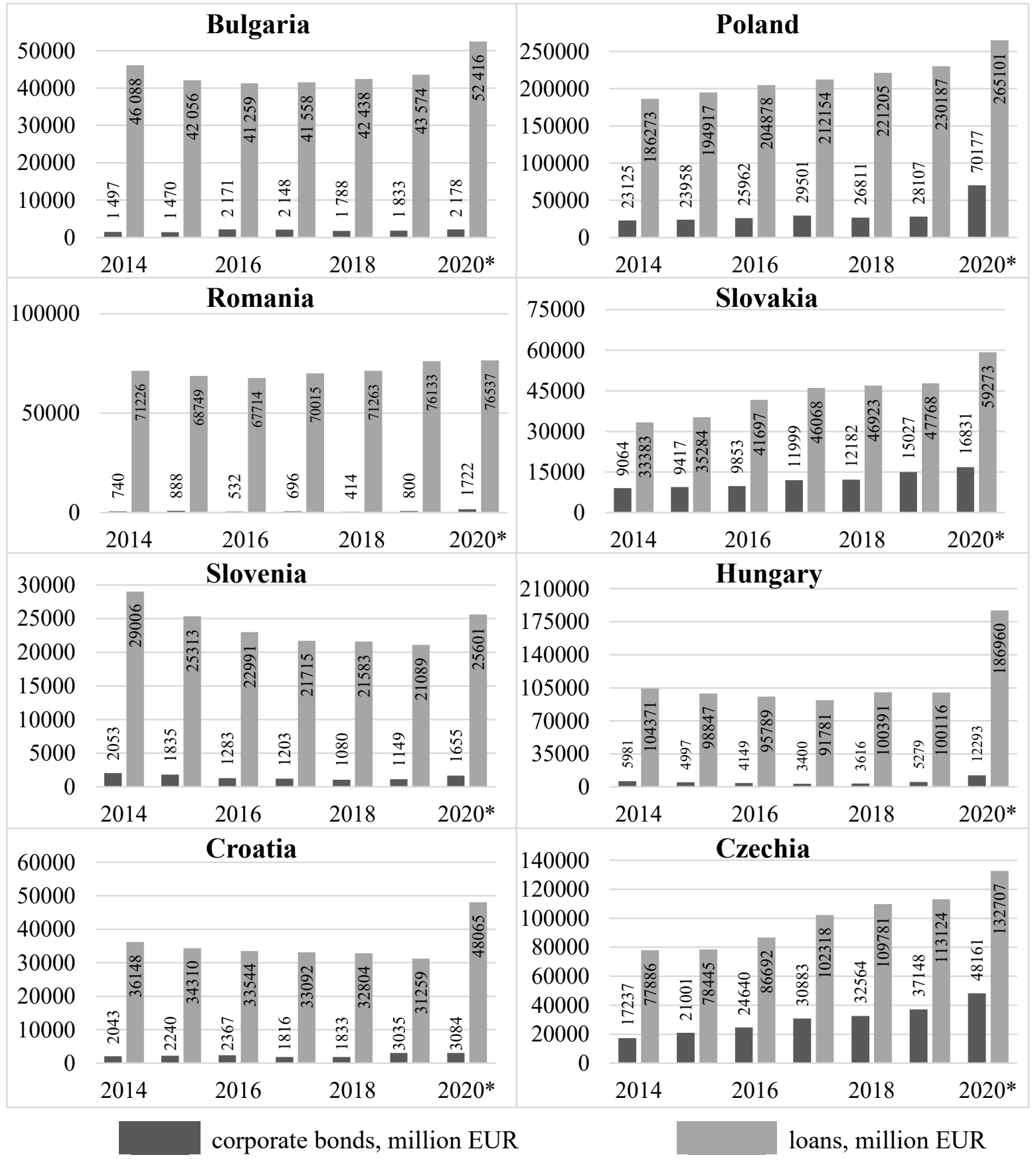

Figure 1. Debt burden on Eastern European corporations (Eurostat, 2020)

excluding banks and insurance companies, and the largest volume of output was in May 2020.

As a result of the analysis of the corporate bond market in Ukraine during 2014-2020, positive changes in the institutional environment were revealed, which consist in a sequel state policy towards foreign investors, growth of corporate governance culture, ensuring transparent financial reporting of enterprises. These shifts are the key factors that will contribute to the development of Ukraine's corporate bond market in the future.

\section{VAR Analysis}

Determining the prospects for the development of the corporate bond market in Ukraine requires the construction of a dynamic model. When assessing the development of the corporate bond market in Ukraine, Kuzheliev M. and Yurova D. relied on indicators of bond trade in the secondary market (Kuzheliev, 2011). However, we consider this indicator to be secondary, as it directly depends on the available amount of corporate bonds.

In the study of Iorhachova M. and Kotsiurubenko H. the main indicator, by which the market development 


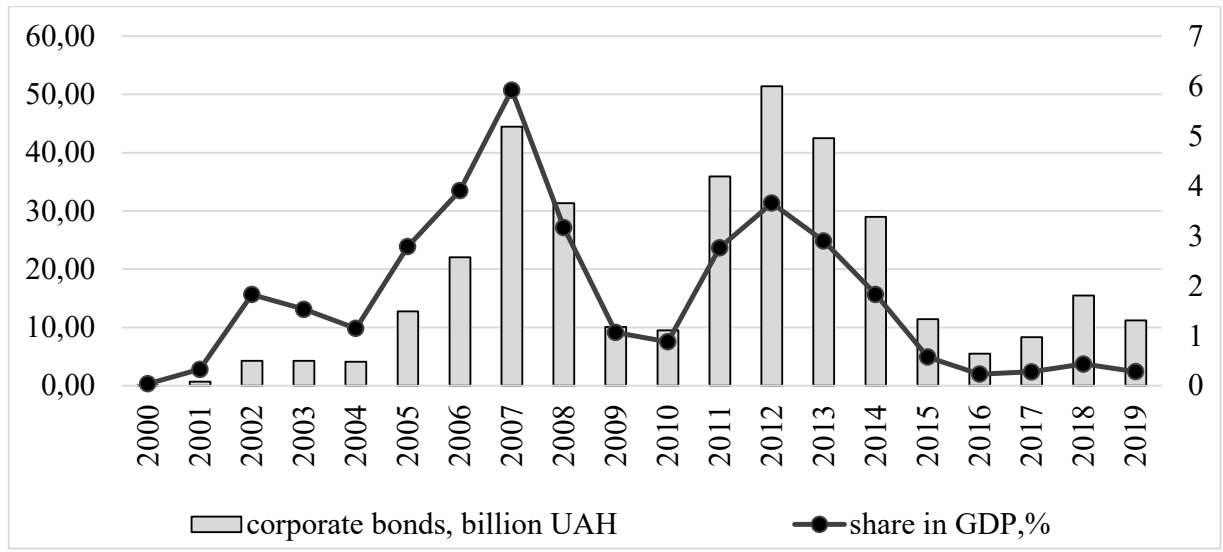

Figure 2. Corporate bond market in Ukraine and its share in GDP, 2000-2019 (National Commission on Securities and Stock Market, 2005-2020; State Statistics Service of Ukraine, 2020)

can be traced, is the amount of corporate bond issued (Iorhachova, 2016). It characterizes the current state of the market, and its increase indicates development. This statement is based on the fact that the availability of a certain amount of the relevant financial instrument determines the volume of trade in the secondary securities market.

The formation of the corporate bond market depends on the markets of other debt instruments. Corporate bonds are seen as a progressive alternative to bank loans. Thus, we assume that reducing the availability of bank loans to the corporate sector will help increase bond issues.

Equity is opposed to corporate bonds source of investment. Investors decide to invest in stocks and bonds, given the state of the economic situation and market conditions. Many authors note a tendency to increase the attractiveness of bonds as opposed to stocks during the crisis (Mustafa, 2015). The investor seeks to invest with less risk during such a market phenomenon, which is caused by a high level of uncertainty about the long-term prospects of equity issuers. Given the distribution of investment resources between the stock market and the bond market, it can be argued that the development of the stock market affects the development of the corporate bond market.

Another aspect that affects the growth of the corporate bond market is the amount of own financial resources, which determines the need to attract debt or equity financial instruments. In this aspect, it is advisable to allocate equity, which depends on the ability of enterprises to normal economic activity and development. Atanasii O., Klymenko S. and Shapovalova A. note that the issue of corporate bonds is one of the ways to optimize the capital structure of the enterprise, i.e. to supplement equity debt (Atanasii, 2019). This indicates the relationship between the level of available equity and the required level of debt capital, which form the amount of financial resources of the enterprise, which is necessary to achieve economic efficiency.

Therefore, we propose to build a vector autoregressive model (VAR) with such variables: the amount of issued corporate bonds, the amount of loans to financial corporations (excluding banks) and nonfinancial corporations, the amount of issued shares and the amount of equity. Vector autoregression (VAR) has become a working model for macroeconomic forecasting. The popularity stems in part from the relative simplicity, flexibility, and ability to match data, but also from success as a prediction device. In practice, VAR is a system of regression models that considers all variables as endogenous and allows each of them to depend on $\mathrm{t}-\mathrm{n}$ lag values of itself and all other variables in the system.

The data for the model are given in Table 1.

In order to form the most reliable model, the coefficients of the equations for different time lags were compared. Therefore, the most accurate is the model with a time lag of one and two years.

As a result of calculations, the following system of equations (1) was obtained.

$$
\left\{\begin{array}{c}
y=9.644+0.861 \cdot y^{-1}-0.814 \cdot y^{-2}+0.028 \cdot x_{1}^{-1}-0.017 \cdot x_{1}^{-2} \\
-0.045 \cdot x_{2}^{-1}-0.1 \cdot x_{2}^{-2}+0.018 \cdot x_{3}^{-1}-0.002 \cdot x_{3}^{-2} \\
x_{1}=11.231+2.407 \cdot y^{-1}+0.421 \cdot y^{-2}+0.684 \cdot x_{1}^{-1}+0.045 \cdot x_{1}^{-2} \\
\quad+0.292 \cdot x_{2}^{-1}-0.106 \cdot x_{2}^{-2}+0.185 \cdot x_{3}^{-1}-0.08 \cdot x_{3}^{-2} \\
x_{2}=-8.567-4.426 \cdot y^{-1}+0.937 \cdot y^{-2}+0.526 \cdot x_{1}^{-1}-0.632 \cdot x_{1}^{-2} \\
-0.424 \cdot x_{2}^{-1}-0.553 \cdot x_{2}^{-2}+0.282 \cdot x_{3}^{-1}+0.027 \cdot x_{3}^{-2} ; \\
x_{3}=256.617+4.356 \cdot y^{-1}-6.881 \cdot y^{-2}+2.645 \cdot x_{1}^{-1}-0.022 \cdot x_{1}^{-2} \\
+0.205 \cdot x_{2}^{-1}-0.23 \cdot x_{2}^{-2}+0.007 \cdot x_{3}^{-1}-0.769 \cdot x_{3}^{-2} ;
\end{array}\right.
$$


Table 1

Data for VAR model

\begin{tabular}{|c|c|c|c|c|}
\hline & $\begin{array}{c}\text { Corporate } \\
\text { bonds }\end{array}$ & $\begin{array}{c}\text { Loans to } \\
\text { corporations }\end{array}$ & Shares & Equity \\
\cline { 2 - 5 } & $\mathrm{y}$ & $\mathrm{x} 1$ & $\mathrm{x} 2$ & $\mathrm{x} 3$ \\
\cline { 2 - 5 } & billion UAH & billion UAH & billion UAH & billion UAH \\
\hline 2000 & 0.07 & 18.47 & 15.49 & 95.52 \\
\hline 2001 & 0.69 & 26.78 & 21.92 & 128.38 \\
\hline 2002 & 4.27 & 38.33 & 12.80 & 144.30 \\
\hline 2003 & 4.24 & 57.89 & 18.02 & 184.62 \\
\hline 2004 & 4.11 & 72.43 & 28.34 & 275.31 \\
\hline 2005 & 12.75 & 107.74 & 24.81 & 315.05 \\
\hline 2006 & 22.07 & 163.19 & 43.54 & 426.58 \\
\hline 2007 & 44.48 & 266.41 & 50.00 & 628.16 \\
\hline 2008 & 31.35 & 453.45 & 46.14 & 691.50 \\
\hline 2009 & 10.11 & 476.23 & 101.07 & 774.42 \\
\hline 2010 & 9.49 & 514.39 & 40.59 & 870.29 \\
\hline 2011 & 35.91 & 591.99 & 58.16 & 967.63 \\
\hline 2012 & 51.39 & 621.65 & 15.84 & 1162.01 \\
\hline 2013 & 42.47 & 711.22 & 64.23 & 1189.73 \\
\hline 2014 & 29.01 & 804.42 & 144.35 & 903.20 \\
\hline 2015 & 11.42 & 803.36 & 122.30 & 1396.13 \\
\hline 2016 & 5.52 & 833.70 & 199.36 & 1491.94 \\
\hline 2017 & 8.35 & 840.87 & 324.84 & 1499.70 \\
\hline 2018 & 15.46 & 868.96 & 22.28 & 1231.14 \\
\hline 2019 & 11.21 & 754.22 & 63.54 & 1329.42 \\
\hline
\end{tabular}

This system (1) allows to develop a forecast of indicators. The dynamics of the model assumes that the current level of each indicator depends on the level of $\mathrm{y}, \mathrm{x} 1, \mathrm{x} 2$ and $\mathrm{x} 3$ in the $\mathrm{t}-1$ period and $\mathrm{t}-$ 2 period. Therefore, forecast indicators were obtained for the amount of corporate bonds, shares, equity and loans to the corporate sector for the period from
2020 to 2024 (Figure 3). In general, the nominal value of the available pool of resources from these sources of financing is expected to increase by $3.4 \%$ annually, which, given the inflation rate, indicates the lack of dynamism of the financial market.

According to the results of the model, the corporate bond market of Ukraine is expected to increase by 2021, in which the issued corporate bonds will amount to 41.59 billion UAH, after which the market is expected to narrow by 9.4 billion UAH, 5.02 billion UAH and 1.98 billion UAH.

The decomposition of the corporate bonds amount shows that the indicator largely depends on the amount of issued shares. Given that the development of the corporate bond market depends on changes in other markets of the financial system, we believe that the declining dynamics is due to the specifics of the formation of other indicators in previous periods. Thus, in 2020, corporations' equity is expected to amount to 1,244.98 billion UAH, and during 2021-2024 its average annual growth rate will be $4.17 \%$. According to the model, the amount of issued shares will be 173.34 billion UAH in 2020, and the average annual growth rate of $26.9 \%$ is expected in $2021-2024$. The amount of loans to corporations will be 763.07 billion UAH (with $5.03 \%$ of the annual growth rate during 2021-2024).

\section{Scenarios for development of the corporate bond market in Ukraine}

We consider the results of the VAR model to be a potential level of indicators that would be achieved under the condition of systematic development of the world and national economy. Given the fact that the

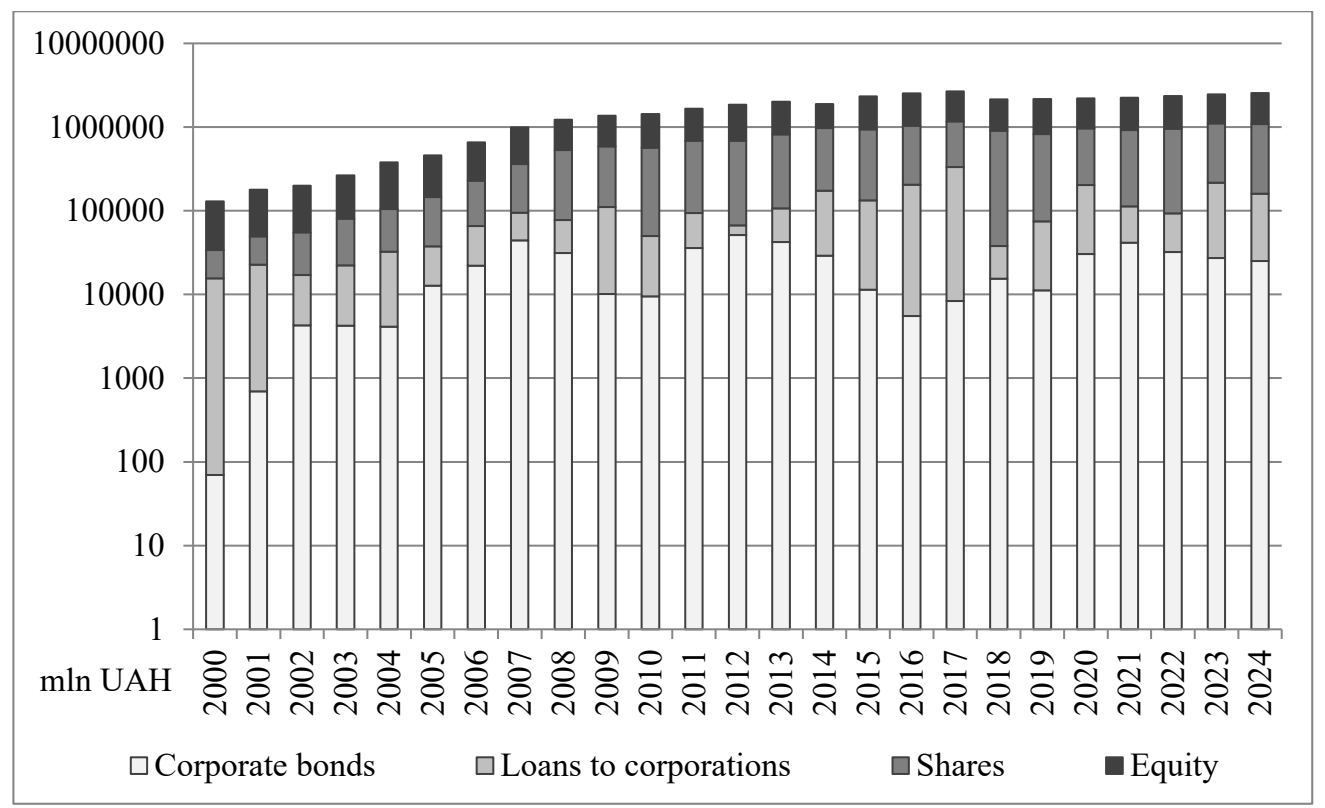

Figure 3. Forecast of corporate bond market development in Ukraine for 2020-2024 
Ukrainian economy is currently in a state of shock due to the deployment of the global coronavirus pandemic COVID-19, there is a need to identify possible scenarios for the development of the corporate bond market. We propose to estimate the changes in the indicators used in the model, provided that their level decreases in 2020 by $10 \%$ compared to the expected level obtained as a result of the VAR model. Therefore, the development of the corporate bond market in Ukraine will be analyzed for each of the following scenarios:

- Scenario A - decrease in the amount of equity;

- Scenario B - decrease in the amount of issued shares;

- Scenario B - decrease in the amount of loans to corporations;

- Scenario A + B - decrease in the amount of equity and issued shares;

- Scenario A + C - decrease in the amount of equity and loans to corporations;

- Scenario B + C - decrease in the amount of issued shares and loans to corporations;

- Scenario A + B + C - decrease in the amount of equity, issued shares and loans to corporations.

Each of the scenarios provides different results for the development of the corporate bond market. Consider them in more detail. According to Scenario A, the amount of equity will decrease, which will significantly affect the corporate bond market. As you know, one of the sources of equity formation of enterprises is retained earnings (Ivchenko, 2016). Accordingly, if as a result of economic activity on the balance sheet of the enterprise remained uncovered loss, the amount of equity is reduced by this amount.

The data set "Main forecast indicators of economic and social development of Ukraine for 2020-2021" states that in 2020 the profits of profitable enterprises are expected to grow by $1.4-12.6 \%$ compared to 2019 , which indicates positive prospects for the development of national economy (Tsykun, 2020). However, the forecast does not take into account companies without profit.

According to Fedulova I. and Dzulai M., the main consequences of COVID-19 for Ukrainian enterprises are the realization of the following risks: change in consumer preferences and consumer demand, reduce of export, purchasing power, production and sales, cessation of production for certain enterprises, unpreparedness for alternative ways to meet demand, the destruction of supply chains (Fedulova, 2020). The peculiarity of these risks is their impact on both SMEs and large enterprises, which indicates a high probability of reducing the amount of equity in the corporate sector.

Therefore, a decrease in equity by $10 \%$ of the potential level will lead to the following changes in the VAR model:

1. The amount of equity will be higher than the potential level by $0.31 \%$ in $2021,11.83 \%$ in 2023 and
$3.12 \%$ in 2024 , and lower by $6.12 \%$ in 2022 . The average annual rate of decline in corporate equity will be $3.41 \%$;

2 . The amount of issued shares will be significantly higher than the potential level. During 2021-2024, there will be an average annual increase by $142.1 \%$;

3 . The amount of loans to the corporate sector will also be higher than the potential level by $7.3 \%$ annually. The average annual growth rate of loans to corporations during 2021-2024 will be 5.19\%;

4. The amount of issued corporate bond will exceed the potential level in 2021 and 2022 by $25.6 \%$ and $11.5 \%$, respectively. However, in 2023 and 2024 there will be a smaller amount of corporate bonds compared to the potential level by $75.8 \%$ and $33.7 \%$ respectively. The average annual growth rate of the corporate bond market during 2021-2024 will be $28.4 \%$.

Scenario B assumes a decrease in issued shares, which may be due to a number of reasons, but the main one to pay attention to in a global pandemic is the liquidation of enterprises, which may be the result of bankruptcy. Therefore, the deployment of this scenario involves the following results:

1. Minor changes in the amount of equity of the corporate sector, i.e. failure to reach the potential level in 2021-2022 (by $0.3 \%$ ) and a slight excess of potential in $2023-2024$ (by $0.12-0.6 \%$ ). The average annual growth rate of the indicator during the period will be $4.18 \%$.

2. The amount of issued shares will exceed the potential level in 2021 and 2024 by $10.3 \%$ and $5.7 \%$, and in 2022 and 2023 will not reach the potential level by $1.1 \%$ and $4.5 \%$, respectively. The average annual growth rate of issued shares will be $26.23 \%$.

3. The amount of loans to the corporate sector will hardly change compared to the potential level: a slight negative deviation in 2021 (by $0.6 \%$ ) and a positive deviation during 2022-2024 (by 0.2-0.5\%). The average annual growth rate of loans will be $5.15 \%$.

4. The amount of issued corporate bond during 2021-2023 will exceed the potential level by $1.2-5.8 \%$, and in 2024 will not reach the potential level by $2.1 \%$. The average annual rate of decrease for corporate bonds during 2021-2024 will be $2.36 \%$.

The next course of events involves a decrease in lending to the corporate sector. Scenario $C$ is quite realistic in a coronavirus pandemic. According to O. Hlushchenko's research, credit quality can deteriorate rapidly, especially in the industries or geographical regions that have suffered the most. This may override existing models of current expected credit losses, which will require more resources to assess the impact of changes in market conditions. Markets can be very volatile for some time, which will be an obstacle in the process of setting interest rates. Rapid changes in liquidity and a sudden drop in demand are already causing some difficulties for market participants who need a "vision" of prices. Similarly, volatility and related dislocations may 
limit the effectiveness of hedging relationships (Hlushchenko, 2020).

From the point of view of financial institutions, the conditions caused by the COVID-19 crisis have specific implications for credit risk management and mitigation. As a result, there is a problem of increasing interest rates on the loan, and thus reducing its availability to businesses. Thus, a decrease in corporate lending by $10 \%$ from the potential level will affect the prospects of the financial market as follows:

1 . The amount of equity of the corporate sector will not reach the potential level during 2021-2024 by $6.3-15.3 \%$. The average annual growth rate will be $2.73 \%$.

2. The amount of issued shares will be lower by $56.2 \%$ in 2021 , by $15.6 \%$ in 2022 and by $12.7 \%$ in 2023 . The amount is expected to exceed the potential level by $1.6 \%$ only in 2024. Nevertheless, the average annual growth rate of shares will be $46.6 \%$.

3 . The amount of loans to the corporate sector during 2021-2024 will not reach the potential level by $8.9 \%$. It should be noted that this will not affect the trend of annual increase in lending, the average growth rate of which will be $5.53 \%$.

4. The amount of corporate bonds issues by analogy with the stock market will not reach the potential level during 2021-2023 by an average of $7.5 \%$, and in 2024 will exceed the potential level by $7.2 \%$. During the study period, there will be a slight average annual decrease of $0.58 \%$.

The combination of scenarios A and B is possibly provided that the total equity of corporations decreases, which occurs against the background of the liquidation of certain corporations and the receipt of uncovered loss by others. It should be noted that the reduction of total equity of corporations by $10 \%$ and the amount of share issues by $10 \%$ implies that the uncovered loss of corporations in 2020 will be $10 \%$ of the difference between equity and authorized capital.

According to the issue of the State Statistics Service of Ukraine (August 25, 2020), the amount of pre-tax profit of large and medium enterprises for January - June 2020 is $89.9 \%$ of the corresponding period of 2019 , and the loss $-316.4 \%$. In addition, the share of unprofitable enterprises increased by $11.7 \%$, which indicates a high probability of Scenario A + B (State Statistics Service of Ukraine, 2020).

Therefore, the forecast indicators of the VAR model will change as follows:

1. The amount of equity will not differ from the potential level in 2021 , will be lower by $6.4 \%$ in 2022 , and in 2023 and 2024 will exceed the potential level by $12.4 \%$ and $3.2 \%$, respectively. Nevertheless, there will be a trend towards an annual decline (the rate of decline will be $3.32 \%$ annually).

2. The amount of issued shares will significantly exceed the potential level in 2021 (3.4 times) and in 2024 (2.3 times), but in 2022 and 2023 the indicator will not reach the potential level by $71.7 \%$ and $67.6 \%$. The latter will not significantly affect the overall dynamics of the stock market growth over a given period of time, as the average annual growth rate will be $156.6 \%$.

3. The dynamics of the loans to the corporate sector will be positive both in comparison with the potential level (exceed by 5.2-12.9\%) and in terms of the average annual growth rate (5.28\%).

4. The amount of corporate bond issues will exceed the potential level in 2021 and 2022 (by $27.5 \%$ and $17.3 \%$ ), in 2023 and 2024 it will not reach the potential level (by $74.6 \%$ and $35.8 \%$ ). The average annual growth rate of the corporate bond market during this period will be $24.74 \%$.

Scenario $\mathrm{A}+\mathrm{C}$ assumes that the decrease in equity due to the accumulation of losses by corporates will lead to high interest rates on bank loans, which will make them less affordable. Therefore, to meet the market demand for financial resources, the volume of the corporate bond market will increase. In this case, the forecast of the model will have the following dynamics:

1. Despite the fact that in 2021, 2022 and 2024 the amount of equity will not reach the potential level by $15 \%, 17.3 \%$ and $3.2 \%$, in 2023 the indicator will exceed the potential level by $5.5 \%$. In addition, the average annual rate of decline in equity will be $3.24 \%$.

2. The amount of issued shares will significantly exceed the potential level in 2021 and 2024, but in 2022 and 2023 will not significantly reach the potential level. Nevertheless, over the forecast period it will exceed the potential level by $35.9 \%$, and will have a significant annual growth rate $(232 \%)$.

3 . The amount of loans to the corporate sector will exceed the potential level by $7.1 \%$ and $1.1 \%$ in 2021 and 2022, but in 2023 and 2024 will not reach the potential level by $5.1 \%$ and $9.4 \%$, respectively. The average growth rate will be $5.84 \%$.

4. The amount of corporate bond issues will significantly exceed the potential level in 2021 (by $20.4 \%$ ), and in 2022, 2023 and 2024 will not reach the potential level by $0.6 \%, 80.9 \%$ and $26.5 \%$, respectively. Nevertheless, it is during this course of events that the highest average annual growth rate of registered corporate bond issues in Ukraine during 2021-2024 will be noted, namely $45.6 \%$.

Scenario B $+\mathrm{C}$ indicates a decrease in demand for bank lending due to the liquidation of a certain share of corporations. It also explains the decrease in total equity. This combination of factors will lead to the following changes:

1. Reducing the availability of these two sources of financing for enterprise development may lead to a significant shortfall in equity during 2021-2024. It is assumed that the amount of equity will not reach the potential level of $5.7-15.6 \%$. Nevertheless, the average annual growth rate will be $2.77 \%$.

2. The amount of issued shares will also not reach the potential level not only in 2020 but also during 2021-2023 (by 16.7-45.9\%), but in 2024 it will exceed 
the potential level by $7.4 \%$. Even given the lower indicators compared to the potential level, the annual growth rate will be $39.18 \%$.

3 . The amount of loans to the corporate sector during 2021-2024 will not reach the potential level by $8.8 \%$, but the annual growth rate will be 5.64\%.

4. Regarding the amount of corporate bond issues, this scenario is one of the worst, as the annual rate of decline will be $12.3 \%$ for 2021-2024. Moreover, the corporate bond market will not reach the potential level in 2021-2023 by $4.5 \%$, and only in 2024 will exceed the potential level by $5.1 \%$.

Another probable scenario is a combination of negative trends in the three indicators, i.e. a decrease in equity, issued shares and loans to corporations (Scenario $A+B+C$ ). It should be noted that the probability of this scenario is quite high, because equity, shares, loans and bonds are elements of the financial market, i.e. are characterized by interdependence. Therefore, a change in even one indicator can immediately affect the change in the rest. This scenario assumes the following forecast of indicators:

1 . The amount of equity will not reach the potential level in 2021, 2022 and 2024 by $15.3 \%, 17.6 \%$ and $3.1 \%$ respectively. In 2023, it will exceed the potential level by $6.1 \%$. Given this, the annual rate of decline will be $3.12 \%$.

2. The amount of issued shares will significantly exceed the potential level in 2021 and 2024 by 2.87 times and 2.34 times, respectively. In 2022 and 2023, the amount will be $12.7 \%$ and $19.7 \%$ of the potential level. The given scenario will guarantee a significant growth rate of the indicator during the forecast period (by $264 \%$ annually).

3 . The amount of loans to the corporate sector will exceed the potential level in 2021 and 2022 (by $6.4 \%$ and $1.3 \%$ ), but in 2023 and 2024 will not reach the potential level (by $4.6 \%$ and $8.9 \%$ ). The average growth rate will be $5.92 \%$.

4. The annual growth rate of corporate bond issues will be the second highest in all scenarios and will be $36.3 \%$, namely: $67.8 \%$ in $2021,-33.5 \%$ in $2022,-83.7 \%$ in 2023 and $226.1 \%$ in 2024 . In addition, the potential level will exceed during 2021-2022 (by 22.3\% and $5.2 \%$ ) and the level will be shortened in 2023 and 2024 (by $79.7 \%$ and $28.6 \%$ ).

Based on the above, the most favorable for the development of the corporate bond market in Ukraine is Scenario $\mathrm{A}+\mathrm{B}$, in which corporations' equity will be reduced by $10 \%$ due to an increase in uncovered loss, but such a reduction will not lead to liquidation of corporations. This scenario assumes the highest annual growth rate of the corporate bond market (45.6\%), namely: $-36.1 \%$ in $2021,-83.8 \%$ in $2022,256.6 \%$ in 2023 and $45.6 \%$ in 2024.

\section{Conclusions}

In recent decades, Eastern European countries, which have made the most progress in market reforms, have developed the stock market and one of its most important segments (the corporate bond market) to such a level that it is gradually beginning to perform its main function of allocating financial resources and cross-sectoral capital flows. The corporate bond markets of Hungary, Slovakia, Poland and the Czech Republic, which rely on a solid legal framework, infrastructure, and an efficient regulatory system, have become attractive to foreign investors, whose rights are secure.

Currently, the corporate bond market of Ukraine is under the influence of positive changes in the institutional environment towards ensuring a consistent government policy regarding foreign investors, growing a culture of corporate governance, ensuring transparent financial reporting of enterprises. The implementation of the EU best practices in regulating the financial market in Ukraine will promote the growth and development of the corporate securities market, and thus allow domestic companies to simplify the process of attracting financial resources from external sources.

According to the dynamic VAR model of corporate bond market development in Ukraine based on data for 2000-2019, by 2021 the corporate bond market of Ukraine is expected to increase to 41.59 billion UAH. During 2022-2024, the annual market is expected to decline by an average of 5.47 billion UAH.

Given the fact that the deployment of the COVID-19 coronavirus pandemic has significantly changed the state of the global and national financial market, adjustments were made to the indicators of equity, issued shares and loans to corporations in 2020 . With the help of scenario forecasting it was found that the most favorable for the corporate bond market of Ukraine is the course of events, in which the amount of equity and loans to corporates in the current year will not reach $10 \%$ of the potential level set by the VAR estimation.

\section{References:}

Atanasii, O. V., Klymenko, S. O., \& Shapovalova, A. A. (2019). Vdoskonalennia struktury kapitalu pidpryiemstva shliakhom formuvannia borhovykh zoboviazan [Improving the capital structure of the enterprise by forming debt obligations]. Ekonomichni studii [Economic studies], vol. 2(24), pp. 13-16.

Ayala Pena, D., Nedeljkovic, M., \& Saborowski, C. (2017). What slice of the pie? The corporate bond market boom in emerging economies. Journal of Financial Stability, vol. 30, pp. 16-35.

Derzhavna sluzhba statystyky Ukrainy [State Statistics Service of Ukraine]. Pokaznyky balansu pidpryiemstv za vydamy ekonomichnoi diialnosti $\mathrm{z}$ rozpodilom na velyki, seredni, mali ta mikropidpryiemstva [Indicators of the 
balance of enterprises by type of economic activity with a division into large, medium, small and micro enterprises]. Retrieved October 25, 2020, from http://www.ukrstat.gov.ua/

European Commission Expert Group (2017). Analysis of European Corporate Bond Markets. Retrieved October 26, 2020, from https: / / ec.europa.eu/info/publications/171120-corporate-bonds-report en

Eurostat (2020). Institutional Sector Accounts. Retrieved October 26, 2020, from https://ec.europa.eu/eurostat/ web/sector-accounts/data/database

Fedulova, I., \& Dzhulai, M. (2020). Ekonomichni naslidky pandemii COVID-19 dlia pidpryiemstv Ukrainy [Economic consequences of the Covid-19 pandemic for Ukrainian enterprises]. Visnyk KNTEU [Bulletin of KNTEU], vol. 4, pp. 74-91.

Gozzi, J., Levine, R., \& Peria, M. (2015). How firms use corporate bond markets under financial globalization. Journal of Banking \& Finance, vol. 58, pp. 532-551.

Haiss, P. R., \& Marin, S. (2003). Corporate Bonds as Financing Vehicle in Central- and Eastern Europe. Proceedings of the 11th Annual Conference on Marketing and Business Strategies for Central and Eastern Europe, Vienna. Retrieved October 24, 2020, from https://ssrn.com/abstract=1317645

Hlushchenko, O. (2020). Aktualni tendentsii finansovoho rynku Ukrainy v umovakh pandemii COVID-19 [Current trends in the financial market of Ukraine in the context of the COVID-19 pandemic]. Zbirnyk naukovykh prats $\Lambda O H O \Sigma[$ Collection of scientific works $\Lambda$ OHO $\Sigma$ ], pp. 47-50.

ICMA (2020). The European investment grade corporate bond secondary market \& the COVID-19 crisis. Retrieved October 26, 2020, from https://www.icmagroup.org/assets/documents/Regulatory/Secondary-markets/TheEuropean-investment-grade-corporate-bond-secondary-market-and-the-COVID-19-crisis-280520.pdf

Iorhachova, M., \& Kotsiurubenko, H. (2016). Rynok oblihatsii v Ukraini: suchasnyi stan ta perspektyvy rozvytku [Bond market in Ukraine: current status and development prospects]. Naukovyi visnyk Odeskoho natsionalnoho ekonomichnoho universytetu [Scientific Bulletin of Odessa National Economic University], vol. 2, pp. 62-78.

IOSCO (2020). Conflicts of interest and associated conduct risks during the debt capital raising process. Retrieved October 26, 2020, from https://www.iosco.org/library/pubdocs/pdf/IOSCOPD661.pdf

Ivchenko, L. V., \& Udovyk, N. L. (2016). Vlasnyi kapital: dzherela formuvannia ta funktsii [Equity: sources of formation and functions]. Molodyi vchenyi [Young scientist], vol. 1(1), pp. 55-59.

Kargar, M. (2020). Corporate bond liquidity during the COVID-19 crisis. National Bureau of Economic Research. Retrieved October 27, 2020, from https://www.nber.org/system/files/working_papers/w27355/w27355.pdf

Kubiczek, J. (2020). Corporate Bond Market in Poland - Prospects for Development. Journal of Risk and Financial Management, vol. 13.12, pp. 306-318.

Kuzheliev, M. O., et al. (2019). Analysis of the current state of the corporate securities market of Ukraine. Financial and credit activity: problems of theory and practice, vol. 2.29, pp. 150-158.

Kuzheliev, M. O., \& Yurova, D. B. (2011). Osnovni tendentsii ta perspektyvy rozvytku rynku korporatyvnykh oblihatsii v Ukraini [The main trends and prospects for the development of the corporate bond market in Ukraine]. Modeliuvannia rehionalnoi ekonomiky [Modeling of the regional economy], vol. 2, pp. 146-154.

Mustafa, N. N. S., Samsudina, S., Shahadanb, F., \& Kam, A. J. Y. (2015). Flight-to-quality between stock and bond markets: Pre and post global financial crisis. Procedia Economics and Finance, vol. 31, pp. 846-855.

Natsionalna komisiia $\mathrm{z}$ tsinnykh paperiv ta fondovoho rynku [National Commission on Securities and Stock Market] (2019). Richnyi zvit Natsionalnoi komisii z tsinnykh paperiv ta fondovoho rynku za 2019 rik [Annual report of the National Commission on Securities and Stock Market for 2019]. Retrieved October 4, 2020, from https: //www.nssmc.gov.ua/document/?id=10666647

Natsionalna komisiia $\mathrm{z}$ tsinnykh paperiv ta fondovoho rynku [National Commission on Securities and Stock Market] (2015). Richnyi zvit NKTsPFR za 2015 rik [Annual report of the National Commission on Securities and Stock Market for 2019]. Retrieved October 9, 2020, from https://www.nssmc.gov.ua/document/?id=10667510

Natsionalna komisiia $\mathrm{z}$ tsinnykh paperiv ta fondovoho rynku [National Commission on Securities and Stock Market]. Richnyi zvit za 2010 rik [Annual report for 2010]. Retrieved October 12, 2020, from https: //www.nssmc.gov.ua/document/?id=10667525

Natsionalna komisiia $\mathrm{z}$ tsinnykh paperiv ta fondovoho rynku [National Commission on Securities and Stock Market]. Zvit za 2005 rik [Annual report for 2005]. Retrieved October 17, 2020, from https://www.nssmc.gov.ua/ document/?id=10667547

Natsionalnyi bank Ukrainy [National Bank of Ukraine] (2020). Dani statystyky finansovoho sektoru [Financial sector statistics]. Retrieved October 22, 2020, from https://bank.gov.ua/ua/statistic/sector-financial/data-sectorfinancial\# $1 \mathrm{~ms}$

OECD (2020). Corporate Bond Market Trends, Emerging Risks and Monetary Policy. Retrieved October 26, 2020, from https://www.oecd.org/corporate/Corporate-Bond-Market-Trends-Emerging-Risks-and-Monetary-Policy.htm State Statistics Service of Ukraine (2020). Ekspres-vypusk "Finansovi rezultaty diialnosti velykykh ta serednikh pidpryiemstv za sichen - cherven 2020 roku" [Express issue "Financial results of large and medium enterprises for January - June 2020"]. Retrieved October 29, 2020, from http://www.ukrstat.gov.ua/express/expr2020/08/103_.pdf Tsykun, I. V. (2020). Osnovni prohnozni pokaznyky ekonomichnoho i sotsialnoho rozvytku Ukrainy na 2020-2021 roky [The main forecast indicators of economic and social development of Ukraine for 2020-2021]. Retrieved October 28, 2020, from https: / / data.gov.ua/dataset/68b7399d-feb8-4f56-9155-bae3e49ed02f 